\title{
PENGARUH INTELLECTUAL CAPITAL TERHADAP RETURN ON ASSET (ROA) PERBANKAN
}

Oleh:

Damar Asih Dwi Rachmawati

damar_adr@yahoo.com

ABSTRAK

\begin{abstract}
Penelitian ini bertujuan untuk mengetahui dan memperoleh bukti empiris tentang pengaruh intellectual capital terhadap Return on Asset (ROA) perbankan.

Penelitian ini termasuk penelitian ex-post facto. Populasi dalam penelitian ini yaitu perusahaan perbankan yang terdaftar di Bank Indonesia periode 2006-2009 dengan sampel sebanyak 68 perusahaan. Teknik pengambilan sample dengan teknik porposive sampling. Variabel dalam penelitian ini terdiri dari satu variabel independen yaitu Intelectual Capital (IC) dan satu variabel dependen yaitu Return on Asset (ROA). Sebelum dilakukan analisis data terlebih dahulu diadakan pengujian prasyarat analisis yang meliputi uji normalitas, autokorelasi dan heteroskedastisitas. Analisis yang digunakan yaitu dengan analisis regresi linear sederhana.
\end{abstract}

Hasil penelitian menunjukkan bahwa terdapat pengaruh positif antara intellectual capital terhadap Return On Asset (ROA). Hal ini dibuktikan dengan nilai koefesien regresi sebesar 0,009 dan hitung lebih besar dari t tabel $(9,650>1,960)$ dengan nilai signifikan signifikansi (p) lebih kecil dari taraf signifikansi $0,05 \quad(0,000<0,05)$. Besar pengaruh yang diberikan intellectual capital terhadap Return On Asset (ROA) sebesar 25,6\%.

Kata kunci: Intellectual Capital (IC), Return on Asset (ROA). 


\section{Jurnal Nominal / Volume I Nomor I / Tahun 2012}

\section{A. PENDAHULUAN}

\section{Latar Belakang}

Seiring dengan makin ketatnya persaingan antar perusahaan akibat adanya pasar bebas dan globalisasi, pada akhirnya menuntut perusahaan untuk mengubah cara mereka menjalankan bisnisnya. Agar terus bertahan, perusahaan-perusahaan tersebut harus dengan cepat mengubah strateginya dari bisnis yang didasarkan pada tenaga kerja (labor-based business) menuju knowledge based business (bisnis berdasarkan pengetahuan), sehingga karakteristik utama perusahaannya menjadi perusahaan berbasis ilmu pengetahuan. Perkembangan ekonomi baru dikendalikan oleh informasi dan pengetahuan, hal ini membawa sebuah peningkatan perhatian intellectual capital sebagai alat untuk menentukan nilai perusahaan (Stewart, 1997; Hong, 2007), sehingga penelitian tentang intellectual capital menjadi sebuah tantangan yang patut dikembangkan.

Praktik akuntansi tradisional tidak mengungkapkan identifikasi dan pengukuran aset tak berwujud (intangible assets) pada organisasi, khususnya organisasi berbasis pengetahuan (International Federation of Accountants, 1998 dalam Hong, 2007; Hong, 2007. Aset tak berwujud (intangible assets) seperti kompetensi staf, hubungan pelanggan, model simulasi, sistem komputer dan administrasi tidak memperoleh pengakuan dalam model keuangan tradisional dan pelaporan manajemen (Stewart, 1997 dalam Hong, 2007). Menurut IAS (Intenational Accounting Standard) 38 tentang Intangible Assets atau aset tak berwujud melarang pengakuan merk yang dibuat secara internal seperti titel penerbitan dan daftar pelanggan, sehingga fenomena ini menyebabkan timbulnya selisih antara nilai buku dan nilai kapitalisasi saham pada banyak perusahaan.

Menurut Abidin (2000), intellectual capital masih belum dikenal secara luas di Indonesia. Hingga saat ini, perusahaan-perusahaan di Indonesia cenderung menggunakan dasar konvensional dalam berbisnis sehingga produk yang dihasilkannya masih miskin kandungan teknologi, banyak sekali aktivitas perusahaan yang didasarkan pengetahuan, keahlian, maupun teknologi, misalnya pengeluaran untuk informasi dan pelatihan. Teknologi masih dicatat sebagai biaya bukan sebagai investasi yang akan mendatangkan keuntungan bagi perusahaan di masa mendatang. Di samping itu, perusahaan-perusahaan tersebut belum memberikan perhatian lebih terhadap human capital, structural capital, dan customer capital, yang merupakan elemen pembangun intellectual capital perusahaan.

Penelitian ini mengukur kinerja intellectual capital sektor perbankan di Indonesia yang diukur dengan menggunakan metode Value Added Intellectual Coefficient (VAIC ${ }^{\mathrm{TM}}$ ) yang dikembangkan oleh Pulic. Dalam metode ini, Pulic berpendapat intellectual capital dihitung dengan suatu ukuran untuk menilai efisiensi dari nilai tambah sebagai hasil dari kemampuan intelektual perusahaan. Komponen utama dari VAIC ${ }^{\text {TM }}$ yang dikembangkan Pulic (1998) tersebut dapat dilihat dari sumber daya perusahaan, yaitu Value Added Capital Employed (VACA), Value Added Human Capital (VAHU) dan Structural Capital Value Added (STVA). Keunggulan metode Pulic adalah karena data yang dibutuhkan relatif mudah diperoleh dari berbagai sumber dan jenis perusahaan. Data yang dibutuhkan untuk menghitung berbagai rasio tersebut ada- 


\section{Jurnal Nominal / Volume I Nomor I / Tahun 2012}

lah angka-angka keuangan yang standar yang umumnya tersedia dari laporan keuangan perusahaan.

Sektor perbankan dipilih sebagai objek ideal penelitian ini karena (1) tersaji data laporan keuangan (neraca, laba/rugi) publikasi yang dapat diakses setiap saat; (2) bisnis sektor perbankan adalah "intellectually" intensif atau industri yang paling intensif dalam pengelolaan intellectual capital (Firer and William 2003) dan (3) secara intelektual karyawan di sektor perbankan lebih homogen dibandingkan dengan sektor ekonomi lainnya (Kubo and Saka 2002).

Penelitia ini menggunakan Return on Asset (ROA) sebagai variabel dependen. Return on Asset (ROA) adalah profitabilitas suatu perusahaan yang diukur dengan menghubungkan antara laba yang diperoleh dari kegiatan pokok perusahaan dengan aset yang dimiliki untuk menghasilkan keuntungan perusahaan. Return on Asset (ROA) adalah salah satu indikator keberhasilan perusahaan untuk menghasilkan laba sehingga semakin tinggi profitabilitas maka semakin tinggi kemampuan untuk menghasilkan laba bagi perusahaan.

Dari pertimbangan tersebut, maka penulis bermaksud melakukan penelitian dengan judul skripsi "Pengaruh Intellectual Capital Terhadap Return on Asset (ROA) Perbankan"

\section{Kajian Teori}

Return On Asset (ROA) merupakan salah satu indikator keberhasilan perusahaan untuk menghasilkan laba sehingga semakin tinggi profitabilitas maka semakin tinggi kemampuan untuk menghasilkan laba bagi perusahaan. Kemampuan perusahaan un- tuk menghasilkan laba dalam kegiatan operasi merupakan fokus utama dalam penilaian prestasi perusahaan. Laba menjadi indikator kemampuan perusahaan dalam memenuhi kewajiban kepada kreditur dan investor, serta merupakan bagian dalam proses penciptaan nilai perusahaan berkaitan dengan prospek perusahaan di masa depan. Return On Asset (ROA) dapat mengukur kemampuan perusahaan menghasilkan laba dengan menggunakan total aset yang dimiliki perusahaan setelah disesuaikan dengan biaya yang digunakan untuk mendanai aset tersebut seperti biaya pengembangan dan pengelolaan karyawan dalam meningkatkan intellectual.

\section{Intellectual Capital}

Beberapa definisi mengenai intellectual capital yang kemudian menjadi standar pendefinisian adalah sebagai berikut :

a. Brooking (1996) mendefinisikan intellectual capital sebagai berikut: "Intellectual capitalis the term given to the combined intangible assets of market, intellectual property, human-centred and infrastructure which enable the company to function".

b. Menurut Sveiby (1998) intellectual capital adalah: "the invisible intanggible part of the balance sheet can be classified as a familly of three, indifidual competence, internal structural, and external structure".

c. Willams (2001) mendefinisikan intellectual capital sebagai proses penciptaan nilai melalui pengetahuan dan informasi yang diaplikasikan pada pekerjaan.

d. The society of Managementt of Canada (SMAC) seperti yang dikutip oleh Hartono (2001) 


\section{Jurnal Nominal / Volume I Nomor I / Tahun 2012}

mendefinisikan intellectual assets sebagai berikut: "In balance sheet intelletual assets are those knowledge-based item, wich the company owns which will produced a future stream of benefits for the company (IFAC: 1998)".

e. Sedangkan Bontis (1998) mengakui bahwa: "Intellectual capitalis elusive, but once it is discovered and exploited, it may provide an organisation with a new resource-base from which to compete and win".

f.. Stewart (1997) menyebut bahwa: "Intellectual capital is intellectual material knowledge, information, intellectual property, experience-that can be put to use to create wealth".

3. Penghitungan Intellectual Capital dengan Metode VAICTM Intellectual capital yang diukur dengan vallue added yang terbentuk dari penjumlahan Value Added Capital Coefficient (VACA), Value Added Human Capital (VAHU), Structural Capital Value Added (STVA) yang disebut dengan nama Vallue Added Intellectual Coefficient (VAIC $\left.{ }^{\mathrm{TM}}\right)$. Formulasi penghitungan Vallue Added Intellectual Coefficient (VAIC ${ }^{\mathrm{TM}}$ ) menggunakan tiga elemen yaitu:

a. Value Added Capital Coefficient (VACA)

VACA adalah perbandingan antara value added (VA) dengan capital employed (CE) atau modal fisik yang bekerja. Rasio ini menunjukkan adanya kontribusi yang dibuat oleh setiap unit capital employed terhadap value added organisasi. VACA menjadi indikator kemampuan intelektual perusahaan untuk memanfaatkan modal fisik yang lebih baik:
Sedangkan VA berasal dari perbandingan antara output dengan input

$\mathrm{VA}=$ Out - In

dimana:

Output (OUT) : Pendapatan bunga bersih + Jumlah pendapatan operasional lain

Input (IN) : Total beban operasional lainnya Beban Personalia

Capital Employed (CE) : Total aktiva - Kewajiban lancer

b. Value Added Human Capital (VAHU)

VAHU adalah rasio dari VA (value added) terhadap HC (human capital), yang menunjukkan kontribusi yang dibuat oleh setiap rupiah yang diinvestasikan pada HC (human capital) untuk value added organisasi, atau hubungan antara VA (value added) dan HC (human capital) mengindikasikan kemampuan HC (human capital) membuat nilai pada sebuah perusahaan. Jadi hubungan antara VA (value added) dan HC (human capital) mengindikasikan kemampuan HC (human capital) membentuk value added dalam perusahaan dengan formula sebagai berikut:

$\mathrm{VAHU}=\mathrm{VA} / \mathrm{HC}$

dimana:

VA (Vallue added) : Output - Input

Output (OUT) : Pendapatan bunga bersih + Jumlah pendapatan operasional lain

Input (IN): Total beban operasional lainnya Beban Personalia

Human Capital (HC) : Beban personalia 
Jurnal Nominal / Volume I Nomor I / Tahun 2012

Ketika VAHU dibandingkan lebih dari sebuah kelompok perusahaan, VAHU menjadi sebuah indikator kualitas sumber daya manusia perusahaan. VAHU juga sebagai kemampuan perusahaan menghasilkan value added setiap rupiah dikeluarkan pada human capital.

\section{c. Structural Capital Value Added (STVA)}

STVA adalah rasio structural capital terhadap value added yang mengukur jumlah SC (structural capital) yang dibutuhkan untuk menghasilkan satu rupiah dari VA (value added). STVA menjadi indikator keberhasilan SC dalam penciptaan nilai.

$\mathrm{STVA}=\mathrm{SC} / \mathrm{VA}$

dimana:

SC (Structural Capital) : VA - HC

VA (Vallue added) : Out put - Input

Output (OUT) : Pendapatan bunga bersih + Jumlah pendapatan operasional lain

Input (IN) : Total beban operasional lainnya Beban Personalia

HC (Human Capital) : Beban personalia

d. Value Added Intellectual Coefficient (VAICTM)

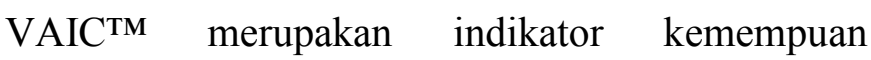
intelektual organisasi atau rasio tersebut merupakan kalkulasi kemampuan intelektual sebuah perusahaan. Formulasi penghitungan VAIC ${ }^{\mathrm{TM}}$ adalah sebagai berikut.

$\mathrm{VAIC}{ }^{\mathrm{TM}}=\mathrm{VACA}+\mathrm{VAHU}+\mathrm{STVA}$

\section{Hipotesis Penelitian}

Berdasarkan deskripsi teori dan kerangka berpikir yang telah diuraikan di atas, maka dapat diajukan hipotesis, yaitu: terdapat pengaruh positif intellectual capital terhadap Return On Asset (ROA) perbankan.

\section{B. METODE PENELITIAN}

\section{a. Jenis Penilitian}

Penelitian ini termasuk penelitian ex-post facto, yaitu "penelitian yang dilakukan untuk meneliti peristiwa yang telah terjadi dan kemudian merunut ke belakang melalui data tersebut untuk mengetahui faktor-faktor yang dapat menyebabkan timbulnya kejadian tersebut. (Sugiyono,2000:3). Jenis penelitian ini juga merupakan penelitian kausal komparatif, yaitu untuk mengetahui pengaruh intellectual capital terhadap ROA (Return on Asset) perbankan.

\section{b. Populasi}

Populasi dalam penelitian ini adalah seluruh perusahaan perbankan yang terdaftar di Bank Indonesia dari tahun 2006-2009 dengan total 145 bank, dengan rincian sebagai berikut: Bank Persero 5 bank, BUSN Devisa 43 bank, BUSN Non Devisa 32 bank, Bank Pembangunan Daerah

26 bank, Bank Campuran 28 bank, Bank Asing 11 bank.

\section{c. Sampel}

Berdasarkan kriteria, hanya diperoleh sampel 68. Berikut ini adalah tabel jumlah sampel yang didapat: 


\section{Jurnal Nominal / Volume I Nomor I / Tahun 2012}

\section{d. Definisi Operasional}

ROA (Return on Asset) merupakan variabel dependen dalam penelitian ini. ROA merefleksikan besarnya hasil yang diperoleh perusahaan atas semua sumber daya keuangan yang telah ditanamkan pada perusahaan. Penghitungan Return on Asset (ROA) menggunakan rumus:

ROA = Laba Bersih Setelah Pajak / Total Aset

Variabel independen dalam penelitian ini yaitu intellectual capital. Intellectual capital adalah pengetahuan yang dimiliki sumber daya manusia yang ada dalam suatu organisasi, terdiri atas tiga komponen yaitu: Value Added Capital Coefficient (VACA) merupakan perbandingan antara vallue added dengan modal fisik yang bekerja di perusahaan. Value Added Human Capital (VAHU) adalah sumber pengetahuan yang berguna bagi perusahaan yang menunjukkan kontribusi yang dibuat perusahaan oleh setiap satu rupiah yang diinvestasikan pada human capital untuk value added suatu organisasi. Structural Capital Value Added (STVA) merupakan indikator keberhasilan Structural Capital dalam pencapaian nilai, STVA merupakan perbandingan structural capital terhadap vallue added yang dapat mengukur jumlah structural capital yang dibutuhkan untuk menghasilkan satu rupiah dari vallue added.

Value Added Intellectual Coefficient (VAIC ${ }^{\text {TM}}$ ) merupakan penjumlahan dari tiga komponen yaitu:

\section{$\mathrm{VAIC}^{\mathrm{TM}}=\mathrm{VACA}+\mathrm{VAHU}+\mathrm{STVA}$}

e. Analisis yang digunakan yaitu dengan analisis regresi linear sederhana. Persamaan yang digunakan dalam peneltian ini adalah:

$\mathrm{ROA}=\mathrm{b}_{0}+\mathrm{b}_{\mathrm{IVAIC}} \mathrm{TM}_{\mathrm{l}}+\varepsilon \varepsilon$
Persamaan tersebut digunakan untuk menguji pengaruh intellectual capital terhadap Return on Asset (ROA) perbankan.

\section{HASIL PENELITIAN}

Hasil analisis regresi linier sederhana menunjukkan bahwa terdapat pengaruh positif antara intellectual capital terhadap Return On Asset (ROA). Hal ini dibuktikan dengan nilai koefesien regresi sebesar 0,009 dan hitung lebih besar dari $t$ tabel $(9,650>1,960)$ dengan nilai signifikan signifikansi (p) lebih kecil dari taraf signifikansi 0,05 $(0,000<0,05)$. Besar pengaruh yang diberikan intellectual capital terhadap Return On Asset (ROA) sebesar $25,6 \%$.
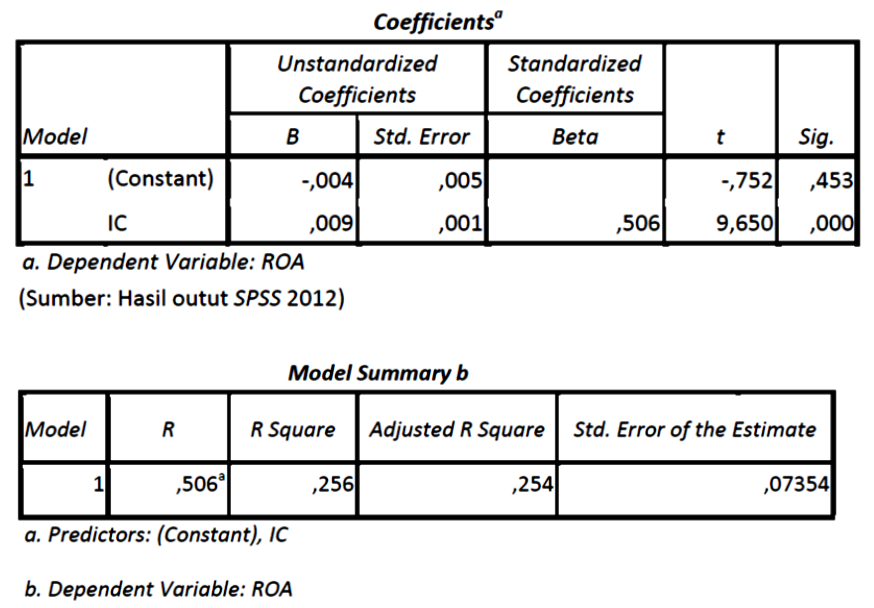

(Sumber: Hasil outut SPSS 2012)

\section{Pembahasan}

Dari penelitian yang teleh dilakukan, diperoleh hasil bahwa intellectual capital memiliki pengaruh yang positif terhadap Return On Asset (ROA) perbankan. Hasil penelitian menunjukkan bahwa hipotesis $\mathrm{Ha}$ diterima sehingga dapat disimpulkan bahwa terdapat pengaruh positif antara intellectual capital sebuah perusahaan perbankan terhadap Return On Asset (ROA). Koefesien regresi yang diperoleh dalam penelitian 


\section{Jurnal Nominal / Volume I Nomor I / Tahun 2012}

ini bernilai positif menunjukkan bahwa arah pengaruh intellectual capital sebuah perusahaan perbankan terhadap Return On Asset (ROA) positif, yang berarti bahwa semakin tinggi nilai intellectual capital sebuah perusahaan perbankan maka ROA (Return on Asset) semakin meningkat. Nilai koefisien determinasi (R2) yang diperoleh pada penelitian ini sebesar 0,256 yang berarti bahwa variabel intellectual capital suatu perusahaan perbankan mempengaruhi ROA (Return on Asset) sebesar $25,6 \%$.

Hasil penelitian ini sesuai dengan penelitian yang dilakukan oleh Ulum (2008) tentang Intellectual Capital Performance Sektor Perbankan di Indonesia. Hasil penelitian ini menunjukkan bahwa hasil pengujian dengan regresi menunjukkan bahwa VA (Value Added) secara dominan ditentukan oleh HC (Human Capital) dan CE (Capital Employed) sebagaimana asumsi model Pulic.

Intellectual capital merupakan komponen yang dimiliki oleh suatu perusahaan dalam mengukur nilai sumber daya manusia didalamnya. Dalam akuntansi, intellectual capital dikategorikan masuk dalam intangible asset (aset tidak berwujud). Namun, pada kenyataannya peran manusia sebagai human capital belum diperlakukan sebagaimana aset yang lainnya yang perlu dibina dan dikembangkan. Intellectual capital adalah hasil penggabungan unsur-unsur utama organisasi yang berbasis pengetahuan yang meliputi, human capital, structural capital dan customer capital untuk menciptakan value added yang pada akhirnya memberikan manfaat ekonomi jangka panjang bagi perusahaan sebagai keunggulan organisasi dalam persaingan dunia usaha. Intellectual capital mempunyai hub- ungan dan peran nyata serta positif baik dalam strategi dan operasional dalam menciptakan nilai pada kemampuan perusahaan untuk menciptakan keunggulan bersaing, sehingga manajemen perlu untuk menaruh perhatian dan mengelola intellectual capital.

\section{PENUTUP}

\section{Kesimpulan}

Penelitian yang dilakukan ini merupakan penelitian kausal komparatif, yang bertujuan untuk mengetahui dan memperoleh bukti tentang pengaruh intellectual capital terhadap Return on Asset (ROA) perbankan yang terdaftar di Bank Indonesia tahun 2006-2009. Berdasarkan hasil analisis, kesimpulan yang dapat diambil dari penelitian ini yaitu adanya pengaruh positif antara intellectual capital terhadap Return On Asset (ROA). Pengaruh positif ini dibuktikan dengan nilai koefesien regresi yang bernilai positif. Hal ini berarti bahwa semakin tinggi nilai intellectual capital sebuah perusahaan perbankan maka Return on Asset (ROA) suatu perusahaan keuangan tersebut semakin meningkat. 